SHS Web of Conferences 10, 00033 (2014)

DOI: $10.1051 /$ shsconf $/ 20141000033$

(C) Owned by the authors, published by EDP Sciences, 2014

\title{
Deficiencies of regulation of euthanasia in legal acts of foreign countries
}

\author{
R. Polaks
}

University of Latvia, Latvia

\begin{abstract}
Today in most countries the practising of euthanasia is not permissible and as in any case of a criminal offence, which endangers the life of a person, criminal liability applies here. However, the analysis of legal norms in foreign criminal codes reveals several deficiencies, ranging from - the absence of legal regulation which leads to a paradoxical situation, when ignoring the motive and aim of the offence, euthanasia is qualified according to the article of the criminal code which provides for liability for murder with no mitigating circumstances, but assisted suicide liability does not apply at all, - to including special legal norms pertaining to this problematic issue, in the structure of criminal codes, in the disposition of which there is an absence of several mandatory constituent elements of these particular criminal offences, thus unduly extending the provision of these norms in practice also in the cases not related to "easy death". The deficiencies of legal acts are observed also in those few countries which allow a definite form of euthanasia and its practising by means of special laws. And most importantly, foreign legislators ignore such forms of terminating the lives of incurably ill persons as active and passive non-voluntary euthanasia, which depending on the nature of the offence requires an appropriate legal framework, which so far has not been observed.
\end{abstract}

\section{Introduction}

Euthanasia or cases when a physician or any other person consciously or out of compassion with his/her own action or omission of action causes, facilitates or does not prevent death of an incurably ill person upon the person's or his/her legal representative's request or without the consent of the above mentioned persons, with the purpose to release the dying person from the excruciating pain and suffering caused by a disease or from a medically unjustified extension of life, is one of the most complex issues subject to regulatory framework, especially because in practice it does not exist in isolation from its separate forms and types, i.e., active voluntary and non-voluntary euthanasia, passive non-voluntary euthanasia, assisted and physician-assisted suicide. The diversity of forms and types of an incurably ill person's termination of life out of compassion and also the interdisciplinary nature of euthanasia do not allow us to address it within the framework of a particular science, thus making the option of choice in the matter of legal regulation more difficult for the legislator when it concerns the regulation which could be accepted as correct, and even more importantly - as fair, which is reflected also in the diversity of foreign regulatory provisions. Taking into consideration the fact that in the legal doctrine, and, thus, also in practice there is no uniform conception of the actions which are included in the conceptual

This is an Open Access article distributed under the terms of the Creative Commons Attribution License 4.0, which permits unrestricted use, distribution, and reproduction in any medium, provided the original work is properly cited. 


\section{SHS Web of Conferences}

understanding of euthanasia, the aim of the research was - to study the present legal regulations of foreign countries concerning euthanasia and as a result of the research to identify the deficiencies in foreign regulations and offer possible solutions.

\section{Materials and methods}

To achieve the aim of the research the analytical, systemic, comparative, inductive, deductive and logical scientific research methods were used in the course of studying foreign legal regulations and practices.

\section{Results and discussion}

Today different legal solutions exist in the national legislation of the world's countries regarding the killing of incurably ill persons out of compassion and one of its independent forms of realization assisted suicide. This allows to relatively divide these countries into two big groups.

In the first group, those countries should be included, whose legislators do not permit the participation of other persons in the termination of incurably ill persons' lives, providing for criminal liability. However, concerning the question under discussion, the legal regulation of these countries is different. That can be explained by both - the national character of the criminal law and by the legislators' individual understanding of the fairness of criminal law. Therefore, the countries belonging to this group can be divided into three subgroups depending on how the issue of "easy death" is regulated, namely:

1. countries where the issue of euthanasia and assisted suicide is not legally regulated, i.e., the legislator has not legalised life termination forms of incurably ill persons, and has not included special legal forms in the national laws which would provide for criminal liability exactly for killing and assisting in suicide out of compassion. However, it should be mentioned that this kind of legal regulation or even ,more precisely, - its absence does not comply with the principle of fairness, and due to the limited scope of the article wider analysis will not be presented;

2. countries where the issue of euthanasia and assisted suicide is legally regulated in the way that only one special norm is included in the national criminal laws and this norm provides for the liability either for:

2.1 active voluntary euthanasia, including in the article a privileged constituent elements and essential lessening of the term of punishment, thus acknowledging that euthanasia is considered to be committed under mitigating circumstances and it should be distinguished from another criminal offence which is similar by aim, but absolutely different by motive, namely murder, for instance, as it is in the Republic of Azerbaijan (article 135), Federal Republic of Germany (article 216), Georgia (article 110), Republic of Korea (article 252 part 1), Republic of Moldova (article 148), Switzerland (article 114), etc. At the same time the liability for assisted suicide is not regulated by the legislator and thus is not considered criminally punishable;

2.2 assisted suicide, as, for instance, in the cases of Argentina (article 83), Bosnia and Herzegovina (article 170 part 1), Brazil (article 122), Republic of Bulgaria (article 127 part 1), Republic of Chile (article 393), Guatemala (article 128 part 1), Republic of Lithuania (article 134), Republic of Malta (article 213), Republic of Nicaragua (article151), Republic of Turkey (article 84 part 1), Venezuela (article 412), etc., but the issue of euthanasia is not regulated separately by the legislator, acknowledging it as a criminal offence, which depending on its form of manifestation and its types in practice, namely - active voluntary and non-voluntary euthanasia or passive non-voluntary euthanasia is punishable in accordance with the provision of criminal code setting out liability for murder or the 


\section{Int. Conf. SOCIETY. HEALTH. WELFARE.}

court acknowledging that the murder was committed in qualifying circumstances, in which the offender was aware of the victim's helpless condition due to illness at the moment of killing;

3. the last group includes the countries where simultaneously two special norms are included in their national criminal laws, i.e., one provides for the liability for euthanasia, while the other one - for assisting in suicide, in that way not only acknowledging that assisted suicide is also considered a separate criminal offence, but also that they should be set apart. Among these countries are the Republic of Austria (article 77 and 78), Bolivia (article 257 and 256), Republic of Croatia (article 94 and 96), Kingdom of Denmark (article 239 and 240), Japan (article 202), Republic of Macedonia (article 124 and 128 part 1), Republic of Montenegro (article 147 and 149 part 2), Paraguay (article 106 and 108), Peru (article 112 and 113), Republic of Poland (article 150 and 151), Portugal (article 134 and 135), Republic of San Marino (article 150 part 3 and article 151 part 1), Republic of Serbia (article 117 and 119 part 2), Spain (article 143 part 2 and 4), etc.

As the positions concerning the issue of euthanasia are controversial, it is also reflected in the dispositions of norms of criminal codes and sanctions, which have included articles on killing out of compassion and/or assisting in suicide. In this connection it is important not only to identify and reveal the differences in the constituent elements of criminal offences which are described in the criminal law of foreign countries, but also to reveal the possible deficiencies and their consequences, beginning the analysis with addressing the issue of active voluntary euthanasia.

Criminal codes of foreign countries contain different constructions of disposition of provisions, which provide for the liability for killing out of compassion and at the request of a person. Not always these differences are characterized positively. This is mainly explained by the condition that quite often there is an absence of all the required constituent elements of a criminal offence set out in legal doctrines and observed in practice.

The motive and aim of the offence should be mentioned as the most important elements characterising the offender's subjective side. However, in the criminal codes of many countries in the provisions concerning liability for killing out of compassion, the legislators do not indicate compassion as the motive of the offence in the dispositions of the articles, as it is, for instance, in Austria, Azerbaijan, Croatia, Denmark, Georgia, Germany, Japan, Moldova, Paraguay, Portugal, Spain and other countries. Although, it could be partly concluded from the titles of the articles, for instance, in Azerbaijan "Euthanasia", in Moldova - "Deprivation of Life upon a Person's Wish (Euthanasia)", in Germany "Killing at the request of the victim; mercy killing", etc. However, objections to such solution should be raised because of two reasons. Firstly, not all the countries have to title the articles in criminal codes. Secondly, not all the titles of the articles indicate the motive. The approach of those legislators who include compassion in the disposition of the provision should be considered more correct. Bolivia, Macedonia, Montenegro, Peru, Poland, Serbia, Switzerland could be mentioned as examples of this approach.

This provision should also be related to the aim of the offence. In Austria, Croatia, Denmark, Germany, Japan, Korea, Macedonia, Montenegro, Moldova, Paraguay, Portugal, Serbia, Spain and other countries it is not indicated. Only in a few countries it is directly included in dispositions, for instance in Azerbaijan - acceleration of death by any means or any actions, or stop of artificial measures on maintenance of life, in Bolivia - to hasten the inevitable death or to terminate a serious illness or incurable injury, in Georgia - to free a dying person from strong physical pain, in Peru - to terminate excruciating pain caused by a terminal illness. However, the legislators' terminological formulations of the aims can be subject to criticism. Georgia can be mentioned as an example. The actions of the offender there can be qualified as such offence only when an incurably ill person has felt physical suffering, although psychiatric illnesses can also create identical sensations. In Bolivia, the use of the formulation "serious illness" included in the disposition of the article in the context of euthanasia, is not 


\section{SHS Web of Conferences}

permissible, due to the fact that, for instance - asthma or diabetes also belong to the category of such illnesses, however the suffering from these illnesses would not be allowed to be terminated by means of euthanasia.

Within the framework of the analysis of composition of legal provisions particular attention should be paid to the manifestation form of the victim's wish, which differs in the criminal codes of foreign countries.

The most common form of expression of will is the victim's "request", as it is in the case of Azerbaijan, Georgia, Germany, Moldova, Peru, Serbia and other states. Another one is an "insistant request", as is the case with Austria, Croatia, Switzerland and some other countries. Some legislators have envisaged in their provisions two alternative forms of expressing the request, as for instance in Japan - "request or consent", in Korea - "request or agreement with the victim", while in San Marino it is only "consent". It should be noted, though, that the person's request should be accepted as legally correct, since the wish to terminate the excruciating pain and suffering caused by an incurable disease should come directly from the subject of the act of euthanasia, not from the third parties.

Concerning the issue of will, not only the form of its expression matters but also the elements characterizing it. In the countries like, for instance, Austria and Switzerland the legislator determines that the victim's request should be "serious and insistent". In Croatia the request should be "earnest", in Germany - "express and earnest", in Montenegro and Serbia - "serious and explicit", in Paraguay - "serious, repeated and insistent", in Peru - "explicit and cognizant", in Spain - "specific, serious, unequivocal request", etc. It should be emphasized that the variety of the demands concerning the requirements of the victim cannot be explained by formal terminological differences.

The characteristics mentioned above, reflect the legislators' understanding of how the appliers of the norms in each country can identify whether the request of the victim for the moment of life termination has been voluntary and well thought over, which is a mandatory characteristic feature of an active voluntary euthanasia. There are also the countries, like for instance, Azerbaijan, Denmark, Japan, Macedonia, Moldova and Poland, where legislators do not consider setting any additional requirements to the victim necessary. It should not be permitted, since in practice it could create difficulties to draw a line of demarcation between active voluntary euthanasia and other criminal offences, which also threaten a person's life.

If in the dispositions of articles of criminal code there is absence of any of obligatory constituent elements of killing out of compassion and upon a person's request, i.e., compassion towards the victim's insistant and serious request, as well as the victim's incurable disease which causes excruciating physical or mental suffering, the legislators have ensured the possibility of wider interpretation of the provisions and their possible practical application in the cases which are not associated with euthanasia, and this should not be admissible.

The analysis of the legal provisions reveals the topicality of another issue which up to now has not been addressed in foreign criminal codes. The issue of active and passive non-voluntary euthanasia has been left unaddressed by the legislators, qualifying these offences according to the provisions of criminal law either as an ordinary murder or murder in aggravating circumstances, i.e., the offender being aware of the victim's helpless state at the moment of committing the offence, even though the motive can be described as compassion towards the victim, thus making a serious legal mistake. The condition that the aforementioned forms of euthanasia and its common types have not gained the legal framework indicates that the issue of "easy death" has not been sufficiently researched in the world, in most cases ignoring the individual elements and in each individual case ignoring the different degree of liability against the consequences.

With regard to the issue under discussion, it is worth considering the legal provisions included in the criminal codes of Montenegro and Macedonia. Article 124 specifies the liability of a person who takes the life of another person with noble motives, while according to Article 147 of the Criminal Code of Montenegro it pertains to the liability for depriving of life of an adult person from compassion due to 


\section{Int. Conf. SOCIETY. HEALTH. WELFARE.}

his serious health condition, or at his serious and explicit request. As is clear from the wording of the articles, their dispositions do not include a mandatory requirement for the existence, which allows the appliers of these norms to subject under this qualification also such offences as active and passive nonvoluntary euthanasia, and, still, by combining three different criminal offences within one disposition framework, denying this solution to be accepted as legally correct. When providing for the punishment and its degree in the sanction of the article, the legislator should always be guided by the principle of fairness, which in the cases of active and passive non-voluntary euthanasia should always be less severe, compared to an ordinary homicide, but more severe than it is in the case of active voluntary euthanasia, since in neither case the victim has given consent to terminate his/her life, but the offender, motivated by compassion, considers that this solution is the only solution to terminate the suffering caused by the illness.

Apart from the differences in dispositions, the disparities in the sanctions of articles can also be observed in foreign criminal codes. With regard to this, it is worth mentioning that practically no logical additional punishment has been provided for this offence in any country, for instance, revocation of the right to occupy certain positions or engage in specified activities that would primarily be applied to cases where the offence would be committed by a special subject.

Unlike killing out of compassion, the legal provisions providing for liability for assisting in suicide are characterised by a lesser degree of concreteness of the constituent elements of the criminal offence included in the dispositions and, therefore, in most cases they are similar in their structure. The legislators of most countries, for instance, Argentina, Austria, Bosnia and Herzegovina, Bolivia, Brazil, Bulgaria, Croatia, Denmark, Guatemala, Japan, Macedonia, Nicaragua, Paraguay, Peru, Poland, Portugal, San Marino, Turkey, Venezuela and some other countries do not differentiate between a simple assistance in suicide whose motive does not manifest itself in compassion to the victim and assisted suicide, in the case of which this motive prevails, and this can also be concluded from the titles of the articles in the countries where they have been planned. Thus, the legislators, putting the equal mark between these two essentially different criminal offences, have made a legal mistake qualifying the actions of the guilty person, when he/she has acted out of compassion and with an aim to relieve an incurably ill person from the excruciating suffering caused by the illness, according to the respective articles of the criminal code, not providing adequate category of liability, where with the logical reduction of the severity of punishment in the cases of "easy death", which is included in the sanctions. In this connection Montenegro and Serbia can be mentioned as good examples in legislation. They have separated these two different assisted forms of suicide in the dispositions of legal provisions, and with the existence of such constituent elements of a criminal offence as compassion to the victim, the victim's insistant and serious request and the victim's incurable disease, stipulating essential lessening of the extent of punishment in the sanction. Even the condition that these two different forms of assisted suicide are included in two separate parts of one article, can not be interpreted as a violation of the construction of legal provisions, since their explicitly individual elements are included in the disposition of legal provisions and their mutual differentiation is clearly visible. The privileged article of assisted suicide is also included in the criminal code of Lithuania. However, it has caused a paradoxical situation, since the legislator does not provide for liability for assisting in a suicide, the motive of which is not compassion and such actions are still not punishable.

Similarly as it is in relation with dispositions, no essential differences are observed also in the sanctions of articles, which provide for the liability for assisting in a suicide, and also for this criminal offence there is the absence of the possible additional punishment - revocation of rights in the criminal codes of most countries.

Comparing the extent of punishments for euthanasia and assisted suicide in the countries whose criminal codes provide for two special provisions simultaneously, it should be concluded that not all the legislators of the countries have noticed and observed the differences in the offender's degree of liability against the consequences which finds reflection in the sanctions of provisions. Therefore the extent of 


\section{SHS Web of Conferences}

punishment in the criminal codes of such countries as, for instance, Austria, Japan, Montenegro, Poland, Portugal, San Marino, etc., for these two different criminal offences are identical. Moreover, for instance in Poland determination of the extent of punishment for euthanasia, individualizing each case, is left for the court to decide, whereas such possibility does not exist as far as assisting in suicide is concerned.

In the context of fairness principle of criminal law the approach of the legislators of Bolivia, Paraguay, Peru and other countries is considered as incomprehensible and actually non permissible when lesser extent of punishment is set out in their legislation for killing out of compassion than it is for assisting in suicide. In this connection it is necessary to emphasize, that when assisting in suicide the liability of the degree of the guilty person against the consequences is always much smaller than in the case of killing out of compassion, since the guilty person only renders assistance in the realization of the victim's intension, and the latter with his/her active actions causes his/her own death, which, in fact, should involve a proportional decrease in the extent of punishment as it is provided for in the criminal codes of Denmark, Macedonia, Serbia and in the criminal codes of other countries.

The second group of countries are those where the legislators with special legal acts acknowledge that terminally ill people have rights to determine the way and time of how to terminate life, thus relieving themselves from the suffering caused by an illness and the doctors have rights to satisfy their patients' request and assist in the process of terminating their lives. Considering the fact that these countries are definitely in the minority and that a wider analysis of their regulatory legal acts has not been envisaged due to the limited scope of the article, an insight into the problematic issues.

Today only the following countries have legalized a particular form and type of euthanasia, namely:

1. The Netherlands where the "Termination of Life on Request and Assisted Suicide (Review Procedures) Act" (Wet toetsing levensbeëindiging op verzoek en hulp bij zelfdoding) came into force on April 1, 2002, with which active voluntary euthanasia and physician-assisted suicide were legalized;

2. Belgium, where "Euthanasia law" (Wet betreffende euthanasie 28 mei 2002), came into force on September 23, 2002. According to this law only active voluntary euthanasia is legalized;

3. Luxembourg, where the "Euthanasia and assisted suicide law" (Loi du 16 mars 2009 sur l'euthanasia et l'assistance au suicide) came into force on March 16, 2009, with which active voluntary euthanasia and physician-assisted suicide were legalized;

4. The USA state of Oregon, where on November 1, 1997 the "Death with Dignity Act" came into force, and the State of Washington, where on March 5, 2009 "The Washington Death with Dignity Act" came into force, and the State of Vermont where on May 20, 2013 "Patient Choice at End of Life bill", came into force, legalizing only physician-assisted suicides.

At this moment no obvious deficiencies are found in the provisions of legal acts providing for prerequisites and order for practising active voluntary and/or physician-assisted suicide. Although the development of the theoretical platform is only one of the preconditions of using such acts of life termination for legal purposes. It is more complicated to provide that the approved regulatory provisions ensure protection of every incurably ill person's endangerment of life, when there is no legitimate aim of it.

One can argue that the legislators of these countries have entrusted the control over the incurably ill persons' life termination act, which is in the process of developing, to the institution of independent physicians who have to carry out the function of the "supervisor", although in most cases it is one person who has the required knowledge in the field of medicine and is subject to the risk of making a mistake. This in the context of the Netherlands has been pointed out by the United Nations Human Rights Committee (Consideration of reports submitted by states parties under article 40 of the covenant), recommending to eliminate the deficiencies. However no changes in the legal acts have been observed.

The formal nature of the control mechanism is not the only problem these countries face. The initial aims of the law, at least currently in the Netherlands, is threatened by court practice, which 


\section{Int. Conf. SOCIETY. HEALTH. WELFARE.}

has not only extended the framework of its activities, but also provided immunity to the doctors against any unsanctioned participation in the processes of terminating lives of incurably ill people, basing the decision on the observing of autonomy of patients and justifiable necessity to release from suffering by all means. Now the Regional euthanasia review committees have also taken over this position, which upon stating violation of law, in most cases finish the case, not even sending it to prosecutor's offices for further inspection. A similar situation is observed also in Belgium.

It can be categorically stated that the Netherland's experience is a vivid negative example of practising assisted suicide, where legislators try to justify all the cases of terminating the patients' lives, which have taken place not observing the legal provisions, giving the "easy death" new shapes and inadmissibly extending the initial limits of the operation of law. In the court practice such cases have been reflected both in the termination of lives of newly born incurably ill infants and also psychiatric patients with prognosticating suffering in their future lives. Today there is a tendency to attribute that also to "existential suffering", losing the link with the diseases classified in medicine, thus deforming the traditional understanding of what euthanasia is and with what purposes its practising was historically started. Moreover, this dangerous tendency is becoming more and more popular in Belgium in terms of new legislative initiatives. Only Luxembourg has accepted the wait-and-see stand which could partly be explained by its comparatively small experience in the issue under discussion.

Unlike the Netherlands and Luxembourg, in the states of Oregon, Washington and Vermont of the USA the law allows the physicians to practice only assisted suicide, thus providing a chance to incurably ill persons who are in the terminal stage, to end their lives in a humane and respectful way, terminating the suffering caused by the illness. However, obtaining the prescription from the physician still does not mean the achieving the aim, since the use of a lethal dosage of medicine, irrespective of the fact whether the physician is or is not present at the moment of committing the act of suicide, on the condition that he/she has no legal rights to interfere in it, not always ensures a fast and effective death. According to the annual reports of supervising institutions, quite often there have been cases when due to the individual nature of a patient's body or due to any other reasons, a patient may vomit the medicine and death sets in a longer period of time than it was planned after using the medicine or does not set in at all. Not interfering with any country's legislator's absolute rights to determine the legal provision most suitable for the country's territorial unit concerning the question under discussion, it is worth indicating that in order to achieve the aim, the legalization of active voluntary euthanasia carried out by a medical professional - a physician, should be considered most logical. No wonder that in the Netherlands and Luxembourg it is mandatory for physicians to be present during the act of suicide to follow the procedure. And now, although it is a controversial issue from the legal point of view, at least in the Netherlands the accepted practice is that in case of any complications which emerge during the act of suicide for reasons not depending on the terminally ill patient, and which endanger its further implementation, the physician has the right to interfere with the process of termination of the patient's life and interrupt the vitality of the body by means of active euthanasia thus ensuring a dignified death, achieving the aim of the law.

However, not only the way of termination of suffering brings about collision with the aim of the law. The laws of the states of Oregon, Washington and Vermont in the USA are in essence discriminatory. For instance, unlike in the Netherlands, Belgium and Luxembourg, the laws pertain only and exclusively to the patients, whose request is based on the physical suffering caused by an illness, thus without a reason, narrowing the conceptual understanding of euthanasia and restricting the rights of psychiatric patients to request the termination of their suffering caused by the illness by means of assisted suicide. Attention should also be paid to the condition that the laws in their current version de facto can not be attributed to those incurably ill people who because of their physiological nature, such as absolute paralysis of the body, are not able to exercise a self-killing act, even if their health status at the moment of expressing the request, formally comply with the requirements of the law, but if someone renders an active assistance in the cessation of the life processes, it is subject to criminal liability. That problem has 


\section{SHS Web of Conferences}

also been emphasized by foreign authors (Jackson, Keown, 2012). One can agree that to these objections a counter-argument can be used, that it is a free choice of a terminally ill person about whether and how to use the means provided for carrying out suicide, and yet, if the legislator recognizes physicianassisted suicide as legitimate in certain conditions, it is also necessary to ensure the practical possibility of its realization for any individual who meets the requirements of the law.

\section{Conclusions}

1. The analysis of the provisions of foreign criminal codes vividly reveal that there is no uniform understanding of the issue of euthanasia, including also assisted suicide. Admitting different constructions of legal provisions and quite often ignoring the obligatory elements of the offences, the legislators permit too expanded interpretation of legal provisions or completely opposite restricted use of these provisions in practice, resulting in legal confusion, and their solutions are not always acknowledged as fair. At the same time such types of euthanasia forms as active and passive non-voluntary euthanasia are not regulated at this moment, ignoring them without any reason and equaling them to an ordinary "murder", although by the motive and aim they are different criminal offences.

2. In the legal provisions of regulatory enactments of the Netherlands, Belgium and Luxembourg there are no obvious deficiencies. However, the court practice of the Netherlands has considerably expanded the framework of the operation of the law, ensuring immunity to the physicians practically against any unsanctioned termination of a patient's life out of compassion, justifying it by circumstances of force majeure which is also to some extent practiced in Belgium, thus unjustifiably deforming the traditional understanding of euthanasia.

3. The physician-assisted suicide laws of the states of Oregon, Washington and Vermont of the USA are discriminatory towards those incurably ill persons, who because of their physiological nature not capable of committing a self-killing act. Besides, the forbiddance of a physician's active participation in the process of termination of life of an incurably ill person or active voluntary euthanasia not always allows to achieve the aim of the law - to ensure dignified death.

4. No law legalizing active voluntary euthanasia and/or physician-assisted suicide actually does not provide for the order of halting life termination act of an incurably ill patient, whereas the legitimacy of the procedures carried out by the physician is examined only after the euthanasia has been carried out. That creates threats to the endangerment of an individual's life, which could partly be prevented by involving the supervising or any other independent institution in the preparation process of life termination act of an incurably ill person, when the patient's request is in the stage of evaluation. In this case they should also be given the right of veto.

\section{References}

[1] Consideration of reports submitted by states parties under article 40 of the covenant. United Nations, Human Rights Committee, 13-31 July 2009, Geneva. Available: http://www. refworld.org/cgi-bin/texis/vtx/rwmain?page=publisher\&publisher $=$ HRC\&type $=\&$ coi $=\&$ docid $=4 \mathrm{aa} 7 \mathrm{aa} 642 \&$ skip $=0$ [viewed on April 26, 2013].

[2] Jackson, E., Keown, J. (2012). Debating Euthanasia. Oxford and Portland, Oregon: Hart Publishing, $131 \mathrm{pp}$.

[3] "Patient Choice at End of Life" bill. Available: http://www.leg.state.vt.us/docs/2014/bills/intro/S077.pdf [viewed on July 26, 2013].

[4] The Oregon Death with Dignity Act. Available: http://public.health.oregon.gov/ ProviderPartnerResources/EvaluationResearch/DeathwithDignityAct/Documents/statute.pdf [viewed on July 26, 2013]. 
Int. Conf. SOCIETY. HEALTH. WELFARE.

[5] The Washington Death with Dignity Act. Available: http://apps.leg.wa.gov/RCW/default. aspx?cite $=70.245$ [viewed on July 26, 2013].

[6] Anonymous (2002). 28 MEI 2002. - Wet betreffende de euthanasie [Euthanasia law]. Belgisch Staatsblad, 22 June 2002, N. 2002 - 2141. (in Dutch).

[7] Wet toetsing levensbeëindiging op verzoek en hulp bij zelfdoding [Termination of Life on Request and Assisted Suicide (Review Procedures) Act]. Available: http://wetten.overheid.nl/ BWBR0012410/geldigheidsdatum_10-06-2013 [viewed on June 10, 2013]. (in Dutch).

[8] Anonymous (2009). Loi du 16 mars 2009 sur l'euthanasie et l'assistance au suicide: Recuel de legislation. [Euthanasia and assisted suicide law]. MEMORIAL Journal Officiel du Grand-Duché de Luxembourg. 2009. 16 mars, A - $\mathrm{N}^{\circ}$ 46. (in French). 